\title{
Using Next-Generation Sequencing to Analyse the Diet of a Highly Endangered Land Snail (Powelliphanta augusta) Feeding on Endemic Earthworms
}

\author{
Stéphane Boyer ${ }^{1,2^{*}}$, Stephen D. Wratten ${ }^{1}$, Andrew Holyoake ${ }^{1}$, Jawad Abdelkrim ${ }^{3,4}$, Robert H. Cruickshank ${ }^{2}$ \\ 1 Bio-Protection Research Centre, Lincoln University, Lincoln, New Zealand, 2 Department of Ecology, Faculty of Agriculture and Life Sciences, Lincoln \\ University, Lincoln, New Zealand, 3 Centre for Reproduction and Genomics, Department of Anatomy \& Structural Biology, University of Otago, Dunedin, New \\ Zealand, 4 Unité Conservation des Espèces, Restauration et Suivi des Populations, UMR 7204, Muséum National d'Histoire Naturelle, Paris, France
}

\begin{abstract}
Predation is often difficult to observe or quantify for species that are rare, very small, aquatic or nocturnal. The assessment of such species' diet can be conducted using molecular methods that target prey DNA remaining in predators' guts and faeces. These techniques do not require high taxonomic expertise, are applicable to soft-bodied prey and allow for identification at the species level. However, for generalist predators, the presence of mixed prey DNA in guts and faeces can be a major impediment as it requires development of specific primers for each potential prey species for standard (Sanger) sequencing. Therefore, next generation sequencing methods have recently been applied to such situations. In this study, we used 454-pyrosequencing to analyse the diet of Powelliphanta augusta, a carnivorous landsnail endemic to New Zealand and critically endangered after most of its natural habitat has been lost to opencast mining. This species was suspected to feed mainly on earthworms. Although earthworm tissue was not detectable in snail faeces, earthworm DNA was still present in sufficient quantity to conduct molecular analyses. Based on faecal samples collected from 46 landsnails, our analysis provided a complete map of the earthwormbased diet of $P$. augusta. Predated species appear to be earthworms that live in the leaf litter or earthworms that come to the soil surface at night to feed on the leaf litter. This indicates that $P$. augusta may not be selective and probably predates any earthworm encountered in the leaf litter. These findings are crucial for selecting future translocation areas for this highly endangered species. The molecular diet analysis protocol used here is particularly appropriate to study the diet of generalist predators that feed on liquid or soft-bodied prey. Because it is non-harmful and non-disturbing for the studied animals, it is also applicable to any species of conservation interest.
\end{abstract}

Citation: Boyer S, Wratten SD, Holyoake A, Abdelkrim J, Cruickshank RH (2013) Using Next-Generation Sequencing to Analyse the Diet of a Highly Endangered Land Snail (Powelliphanta augusta) Feeding on Endemic Earthworms. PLoS ONE 8(9): e75962. doi:10.1371/journal.pone.0075962

Editor: Robert J Forster, Agriculture and Agri-Food Canada, Canada

Received May 17, 2013; Accepted August 19, 2013; Published September 27, 2013

Copyright: $\odot 2013$ Boyer et al. This is an open-access article distributed under the terms of the Creative Commons Attribution License, which permits unrestricted use, distribution, and reproduction in any medium, provided the original author and source are credited.

Funding: This work was funded by Solid Energy New Zealand Limited and supported by the Department of Ecology at Lincoln University and the BioProtection Research Centre at Lincoln University. The funders had no role in study design, data collection and analysis, decision to publish, or preparation of the manuscript.

Competing interests: The authors have declared that no competing interests exist.

*E-mail: Stephane.Boyer@lincoln.ac.nz

\section{Introduction}

\section{Molecular analysis of animal diets}

The study of animal diets is of major importance in conservation biology and in biological control of pests (e.g. [1-6]). The classical approach to diet analysis often relies on the morphological examination of gut content or faeces. Remains such as plant leaves and seeds, insect cuticle, mammalian hairs and teeth can be retrieved and identified to species or higher taxa based on their morphology. However, this method often lacks precision at the species level particularly for predators that feed on soft-bodied prey such as molluscs or earthworms and predators that masticate their prey thoroughly such as bats [7]. It is also not applicable to species that feed on liquid (e.g. Hemiptera, spiders etc.).

Molecular techniques targeting prey DNA remaining in gut or faeces of predators [8] can be a useful alternative to morphological methods because (i) it allows identification at the species level providing that those species have been sequenced before, (ii) it is applicable to soft-bodied prey, and (iii) it is applicable to liquid feeders. These techniques are based on the use of polymerase chain reactions (PCR) on prey DNA remaining in predators' guts or faeces.

Therefore, molecular methods have been recently applied to study the diet of various species for which feeding is difficult to observe or quantify. These include species that are very small [9], aquatic [10] nocturnal [7] or elusive [11]. 


\begin{tabular}{|l|l|l|l|l|l|l|}
\hline 19 & 10 & 20 & Amplified worm sequence (134) & 20 & 10 & 19 \\
\hline
\end{tabular}

Figure 1. Modified primer used for PCR amplification prior to 454-pyrosequencing. Pyrosequencing fusion primers were as recommended by the manufacturer (Roche), molecular tags were as recommended by Parameswaran et al. (2007) [45] and New Zealand endemic earthworm group-specific primers were as described in Boyer et al. (2011) [15].

doi: 10.1371/journal.pone.0075962.g001

One important limitation of these methods is the degradation of prey DNA through digestion. This leads to mainly small DNA fragments surviving digestion, so that recently eaten prey (in gut samples) are easier to detect than are prey eaten earlier (in faeces). However, in the case of endangered predator species it is not desirable to sacrifice individuals to study their diet. Therefore, from a conservation perspective, gut content samples can only be sourced from fresh, accidentally killed, individuals [e.g. [12]] while faecal samples can be much easier to obtain [e.g. [13]].

\section{Faecal molecular analyses}

Despite its easy collection, the analysis of prey DNA from predator faeces faces several technical challenges [14,15].

(1) Because DNA is degraded during digestion, little prey DNA can be retrieved from the faeces and only small fragments of it remain $[16,17]$. Therefore, for optimal efficiency, the PCR primers must target a short DNA fragment. Reliable PCR results from digested DNA have been obtained using fragments of less than 300 base pairs [18-22]. Furthermore, mitochondrial and ribosomal DNA, are more likely to be retrieved than nuclear DNA after digestion due to high copy number per cell [8].

(2) Faeces may contain a mix of DNA from different prey species, the predator itself, gut bacteria, parasites and accidentally swallowed items. Therefore identification of the predated species requires specific primers [e.g. [8]]. For generalist predators, this method is very demanding, as specific primers need to be designed and tested for each potential prey species [23]. It follows that DNA of unsuspected prey would remain unnoticed. Group-specific primers can be used to focus on a particular group of closely related species. However, when DNA from several species of prey is present in one faecal sample, group-specific primers and conventional Sanger sequencing are not compatible [e.g. [15]] as the latter requires there to be thousands of copies of the same DNA fragment to produce a consensus sequence.

(3) As a consequence, once prey DNA has been amplified from predator faeces, post-PCR processing such as highresolution melting (HRM) [e.g. [24]], single-strand conformational polymorphism (SSCP) [25], restriction fragment length polymorphism (RFLP) [e.g. [26]], denaturing gradient gel electrophoresis (DGGE) (e.g. [27]), or subcloning (e.g. [16,28]) is required to separate DNA from different prey species. Identification of predated species also requires prior establishment of the behaviour of each of the potential species' DNA in the chosen post-PCR process. This can be timeconsuming and requires much laboratory work, which increases the risk of errors and becomes expensive if a large number of samples need to be analysed.
Next-generation sequencing (NGS) technologies such as 454-pyrosequencing offer a much simpler alternative by detecting and sequencing many thousands of DNA fragments simultaneously from mixed samples [29-31]. Pyrosequencing has been used largely for whole genome sequencing and the sequencing of environmental DNA samples [31,32]. Recently it has been successfully applied to diet analysis both under controlled feeding conditions [33] and for wild animals [13].

In this study we used 454-pyrosequencing to investigate the earthworm-based diet of Powelliphanta augusta Walker Trewick \& Barker [34] (Mollusca: Pulmonata: Rhytididae), a highly endangered species of land snail endemic to New Zealand [35]. The original habitat of $P$. augusta is Mount Augustus on the western scarp of the Stockton Plateau (West Coast of New Zealand's South Island) most of which was lost to open-cast coal mining at the Stockton mine in 2007. Following a decision from the environmental court of New Zealand, a systematic collection campaign was launched in 2006 by the mining company Solid Energy New Zealand Limited in conjunction with the New Zealand Department of Conservation to conserve the species and allow the mining operations to continue. Hand-collected individuals (6140 snails of various age and 1116 eggs) were either relocated to adjacent undisturbed areas outside the planned mine footprint or kept and cultured in captivity for re-introduction once the original site has been rehabilitated after coal extraction (c. 10 years). Although previous studies have shown that $P$. augusta almost exclusively feeds on earthworms [15], the identity of the predated species as well as their relative contributions remains unknown. This study aims at providing a detailed analysis of the snail's diet to inform the conservation programme and ensure long-term survival of relocated and captive populations.

\section{Materials and Methods}

\section{Ethics statement}

$P$. augusta snails collected in the field were placed in individual clean plastic containers for 48 hours in appropriate moisture and temperature conditions. Only the faecal strings produced during that time were retained for DNA analysis. Faeces were naturally excreted. Snails were returned to the wild, unharmed, after the two day holding period.

Animal handling and sampling methods were conducted according to relevant national and international guidelines. All necessary permits were obtained from the New Zealand Department of Conservation (permit numbers: WC-19030-FAU and WC-25283-FAU). These permits were issued under section 53 of the Wildlife Act 1953. 


\section{Land snail faecal samples}

Molecular analyses were conducted on 46 snail faecal strings obtained from 46 different individuals collected from the field in November 2006 and May 2007. Because earthworms' soft bodies leave no recognisable tissue that could be analysed individually after digestion by the snails [15], DNA extractions were performed on a bulk sample of each snail faecal string. The Qiagen DNeasy ${ }^{\circledR}$ blood and tissue kit was used to extract DNA from snail faeces. Snail diet was compared in relation to snail age, with the aim of detecting potential ontogenic shifts. Snail age was estimated by the maximum diameter of their shell; four categories were distinguished: hatchlings $<13 \mathrm{~mm}$; juveniles $<20 \mathrm{~mm}$; sub-adults $<32 \mathrm{~mm}$; and adults $\geq 32 \mathrm{~mm}$.

\section{Earthworm DNA library, mini-barcode selection and molecular tags}

Previous morphological and molecular analysis of faecal samples revealed that the diet of $P$. augusta is mainly based on endemic New Zealand earthworms (Oligochaeta: Acanthodrilidae, Megascolecidae) [15]. An inventory of earthworms on the Stockton plateau was made from 2008 to 2010 and involved the collection of more than 1,500 individuals [36] from the remainder of the original range of $P$. augusta as well as similar habitat in surrounding areas [37]. Based on this inventory, a DNA library for all potentially predated earthworm species was built using DNA sequences from 139 earthworm specimens, selected to maximize taxonomic representation.

The mitochondrial 16S rDNA gene was chosen for species delineation, as this molecular marker is suitable for earthworm taxonomy, both at genus and species level $[38,39]$.

The obtained DNA library included 15 clades separated by genetic differences greater than $10 \%$. Based on this divergence, those clades were recognised as different species [36]. Most of these species are yet to be described; however, four of them have been identified based on previous taxonomic descriptions [40,41]. These four are: Deinodrilus gorgon Blakemore (referred to as species 1 in this study); Eudinodriloides forsteri Lee (referred to as species 3 in this study); Octochaetus kenleei Blakemore (referred to as species 7 in this study); and Maoridrilus felix Blakemore (referred to as species 9 in this study).

The sliding window function available in the $R$ package SPIDER (Species Identity and Evolution in R) [42] was used to determine the shortest DNA fragment or 'mini-barcode' that displayed enough variability to accurately identify all earthworm species occurring in the snails' geographic range [43]. The selected mini-barcode was a $134 \mathrm{bp}$ fragment starting at position 11922 of the published Lumbricus terrestris Linnaeus mitochondrial genome sequence [44]. Group-specific primers designed to amplify this mini-barcode in New Zealand endemic earthworms [43] were: primer A (nz worm 16S int F) 5' AATTMGGTTGGGGCGACSHW-3' ; primer B (nz worm 16S int R) 5'-AACATCGAGGTGCCAAWCCC-3. These were modified for 454-pyrosequencing with fusion primers added at both ends according to the manufacturer's recommendation for the Roche Genome Sequencer FLX System and molecular identifiers (MID) of 10 base pairs [45] included between the fusion primers and the group specific primers (Figure 1). The MID ensure that the origin of each amplicon could be traced, i.e., which snail faecal string they were derived from, thus allowing the analysis of individual snail diet and comparison between snail age classes. Statistical analyses (ANOVA, permutational multivariate analysis of variance and $F$-test) were performed in $\mathrm{R}[46]$ using the packages stats and vegan.

\section{Nested PCR protocol}

To optimise the amplification of earthworm DNA from snail faeces, a nested PCR approach was used. This consisted of a first PCR using a pair of universal invertebrate primers (LR$\mathrm{J}-12887$ and LR-N-13398 [47]), which amplify a 200 base pair fragment of the $16 \mathrm{~S}$ mitochondrial gene, followed by a $10 \mathrm{x}$ dilution of the PCR products and a second (nested) PCR using the modified group-specific primers described above (Figure 1), which amplify a 134 base pair fragment. Each PCR product contained a unique molecular tag corresponding to the land snail faecal string from which it came.

For both PCRs, the $25 \mu$ l reactions contained $5 \mu$ l Qiagen $Q$ solution, $2.5 \mu \mathrm{l} 10 \mathrm{X}$ buffer (Invitrogen), $2.5 \mu \mathrm{l}$ dNTPs [2.5mM each], $1 \mu \mathrm{l} \mathrm{MgCl}_{2}$ [25mM], $1 \mu \mathrm{l}$ Bovine Serum Albumin [10mg/ $\mathrm{ml}$ ], $0.5 \mu \mathrm{l}$ forward and $0.5 \mu \mathrm{l}$ reverse primers $[10 \mu \mathrm{M}], 0.3 \mu \mathrm{l}$ Invitrogen Taq DNA polymerase [5unit/ $\mu \mathrm{l}], 1 \mu \mathrm{l}$ DNA template and $10.7 \mu \mathrm{l}$ water. The thermocycler protocol comprised a $4 \mathrm{~min}$ initial denaturation (at $94^{\circ} \mathrm{C}$ ) followed by 40 cycles of $1 \mathrm{~min}$ denaturation (at $94^{\circ} \mathrm{C}$ ), $1 \mathrm{~min}$ annealing (at $51^{\circ} \mathrm{C}$ for universal primers and $63^{\circ} \mathrm{C}$ for group specific primers) and $1.5 \mathrm{~min}$ elongation (at $72^{\circ} \mathrm{C}$ ). Annealing temperature was elevated to $63^{\circ} \mathrm{C}$ to enhance group-specific primer specificity during the second (nested) PCR. Filter tips and negative controls were used throughout the nested PCR to control for false positives and avoid contamination.

PCR products were processed through electrophoresis on a $1.5 \%$ agarose gel, followed by a gel extraction of the banding patterns and DNA purification (Qiagen Qiaquick@ PCR gel extraction kit). All PCR products were diluted to the same concentration of $0.5 \mathrm{ng} \mathrm{\mu l}^{-1}$ to provide an even contribution from each individual snail, should it be a big adult or a very small juvenile. PCR products were pooled to make a unique $0.5 \mathrm{ng}$ $\mu^{-1}$ DNA sample following the manufacturer's recommendation for the Roche Genome Sequencer FLX System.

\section{BLAST analyses}

Short DNA sequences, or 'reads', obtained by 454pyrosequencing were compared to our earthworm DNA library (containing 15 species) using the BLAST programme [48]. Only reads of expected length and containing at least one complete primer were kept. BLAST 'hits' were used to assign reads to one of the reference earthworm species and statistical significance was measured by the $\mathrm{E}$-value provided by the BLAST programme. The E-value describes the random background 'noise' that exists for matches between sequences, with high significance reached for $E$-value $<1 e-5$. To assure conservative identification, reads were assigned to one reference species only when they had either a single hit with Evalue $<1 \mathrm{e}-5$ or multiple hits with the second best hit being clearly much worse than the top hit (i.e., top hit E-value / second hit E-value < 1e-5). Reads that did not fulfil these 


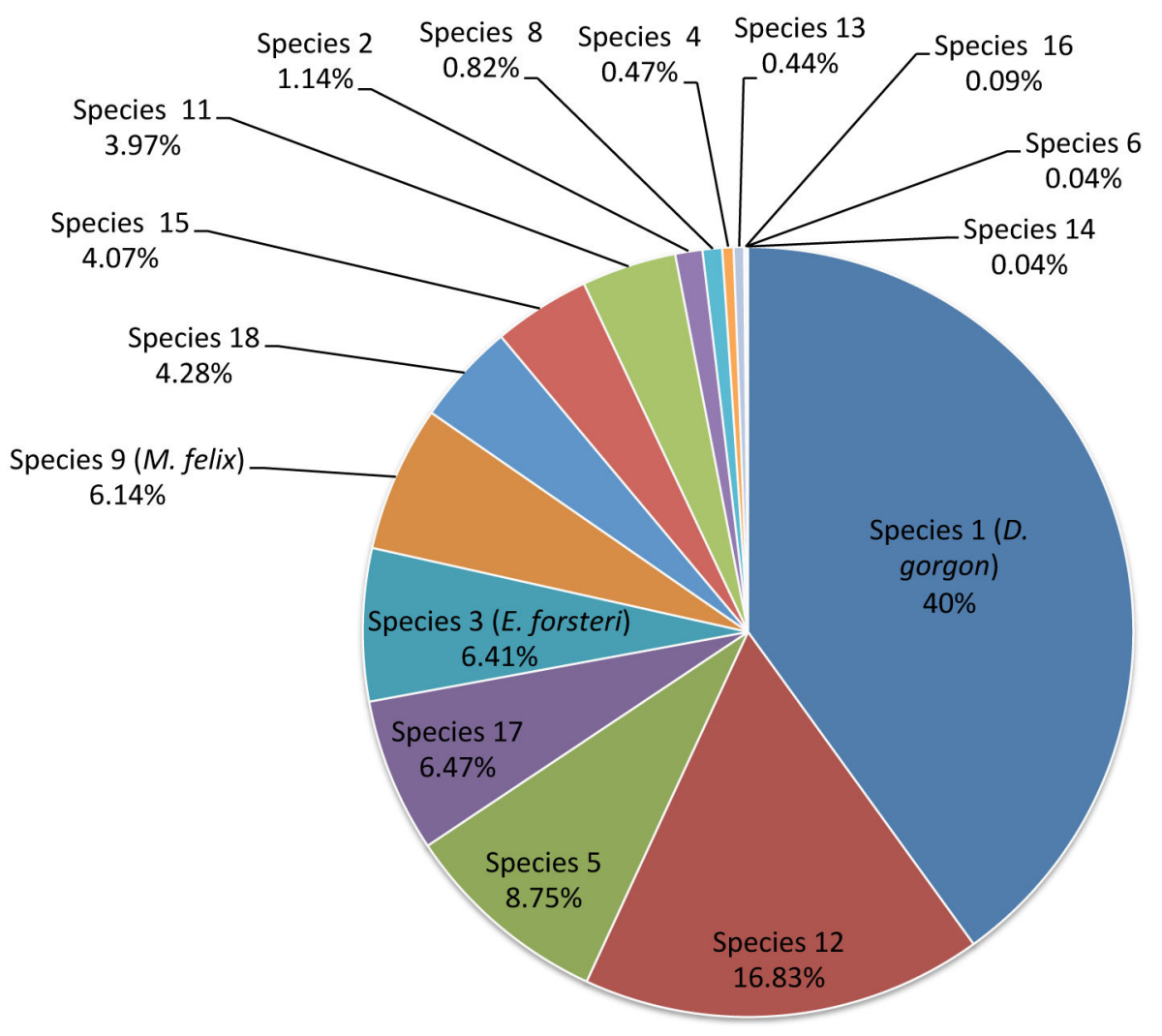

Figure 2. Breakdown of predated earthworm species. Proportion of the 8,712 good-quality amplicons from each of 16 different earthworm species based on amplicons obtained after 454-pyrosequencing on 46 snail faecal strings.

doi: 10.1371/journal.pone.0075962.g002

conditions were compared to the Genbank database using the BLASTn algorithm to confirm that they corresponded to earthworm DNA. If so, they were considered additional species (i.e., not present in the DNA library). The quality of DNA reads was measured using Phred [49] and only sequences with Phred score $>30$ (i.e. base call accuracy $>99.9 \%$ ) were used. Also, amplicons with unexpected lengths ( $<120 \mathrm{bp}$ or $>160 \mathrm{bp}$ ), amplicons lacking a complete primer and amplicons detected less than 5 times in total were considered as potential chimeric sequences or PCR artefacts and were discarded. The complete dataset has been deposited in a NCBI Bioproject (http://www.ncbi.nlm.nih.gov/bioproject) under the accession number PRJNA210725.

\section{Results}

The pyrosequencing analysis revealed the presence of earthworm DNA in 35 of the 46 snail faecal samples. The proportion of samples where earthworm DNA was not detected was similar across age classes (15 to 22\%) except for hatchlings where two samples out of three were negative. $A$ total of 8,742 DNA fragments were successfully amplified and sequenced from the 35 faecal samples that contained earthworm DNA. BLAST analysis of all good-quality amplicons revealed that $7,120(83 \%)$ of them matched with one of the species in the earthworm DNA library. Thirteen species from the library were detected while two of them (species 7 and 10) were absent from the faecal samples. The remaining amplicons (17\%) corresponded to three additional taxa that were not present in the original earthworm library. Because divergence from the closest library species was greater than $7.5 \%$, these taxa were considered as three additional species and noted species 16, species 17 and species 18 thereafter. The breakdown of amplicons per species of earthworm shows that one species in particular (species 1, D. gorgon) was most frequent in the sequence data, with $40 \%$ of all amplified amplicons corresponding to that species (Figure 2). Most faecal samples contained DNA from several species of earthworms (Figure 3). The mean number of earthworm species present in one snail faecal string was $3.4( \pm 0.4)$. No differences were observed in relation to snails' age class for the number of species predated (ANOVA, $F_{4,30}=1.6843 p=$ $0.1796)$ or which species had been consumed $\left(F\right.$-test, $\mathrm{F}_{1,9}=$ $0.790, p=0.752)$. Species 1 (D. gorgon) and species 12 were predated by most snails, with their DNA present in $94 \%$ and $86 \%$ of the faecal strings respectively (Figure 4 ). Other highlypredated species were species 5 and species 9 (M. felix) found in $63 \%, 57 \%$ of the faecal strings, and to a lesser extent species 15 and 11 found in $51 \%$ and $43 \%$ of the faecal strings. Species 2, 3 (E. forsteri), 4, 8, 17 and 18 were occasionally 


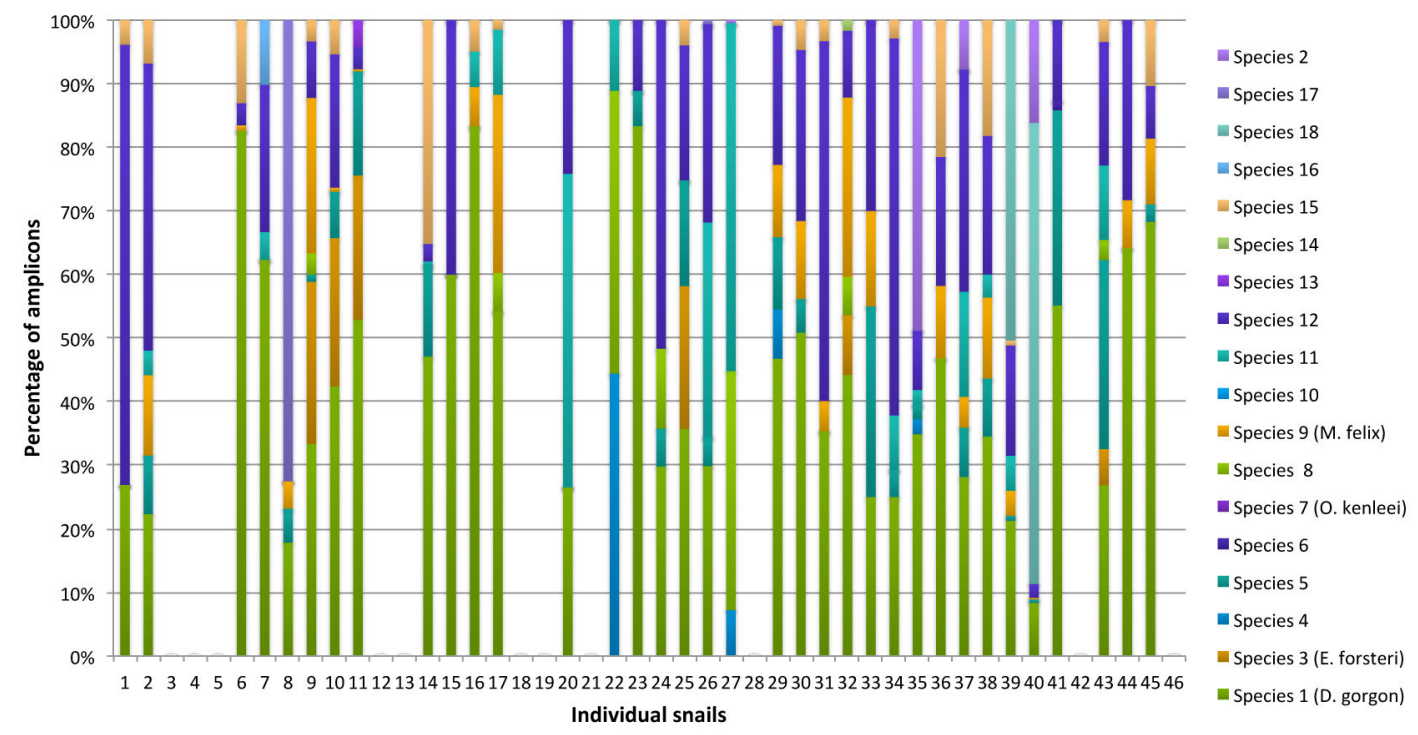

Figure 3. Individual diet composition for 46 Powelliphanta augusta snails. Percentage of amplicons detected for each earthworm species in each faecal string $(n=46)$.

doi: 10.1371/journal.pone.0075962.g003

predated (present in $6-20 \%$ of the faecal samples); species 6 , 13,14 , and 16 were rarely predated (typically found in one faecal sample only) and species 7 (O. kenleei) and species 10 were not predated by any of the snails (Figure 4).

\section{Discussion}

\section{Diet composition of $P$. augusta}

The molecular diet analysis protocol used here allowed the amplification, sequencing and identification of 16 different species of earthworms comprising the diet of $35 P$. augusta snails. Based on these samples, no ontogenetic shift was observed in the diet of the snail, however, sample size was very limited for the youngest age class. This mollusc appears to be able to feed on a wide variety of earthworm species since all but two of the species inventoried in their distribution area were detected in their faeces. This result partly supports the current use of the exotic earthworm Eisenia fetida Bouché [50] as a food source for the captive population of $P$. augusta (pers. obs.). An important limitation of molecular diet analysis is that, due to differences in prey size, it is difficult to quantify the relative contribution of each prey species in the diet [51]. The relative amounts of each amplicon do not necessarily provide an accurate quantification of the contribution of each predated species to the snails' overall diet. Rather they merely reflect the amount of prey DNA, which can be influenced by the size of the predated earthworm (large species are likely to produce more amplicons), the time since consumption (earthworms eaten earlier are likely to produce fewer amplicons) and possible molecular bias in favor of certain species (i.e., some amplicons may be more prone to amplification than others). Quantitative PCR (qPCR) has been used to estimate the relative quantity of each prey species in faecal samples but this requires careful validation with strictly controlled feeding trials [51], which are often not achievable for the species of interest. As an alternative to qPCR, the use of molecular tags [45] allowed an estimation of the proportion of faeces containing DNA from a particular species of earthworm, which is a surrogate for the proportion of individual snails predating that species. This provided a good estimate of the importance of each prey species in the diet of these snails as a whole, and showed that snails of all ages had comparable diets, with certain species of earthworms consistently predated more than others. In a recent study, Murray et al. [52] indicated that 454pyrosequencing provides a very similar estimation of prey quantities when compared to qPCR. However in our study, the proportion of amplicons obtained from 454-pyrosequencing appears as a poor estimate of the diet. For example, species 17 , which was the fourth most important source of amplicons over all faecal samples (Figure 2), was only predated by two individual snails (Figure 4).

Because little is known about these earthworms, it is difficult to assess why certain species are predated more than others. As suggested in a previous paper these snails may indiscriminately eat earthworms as they are found rather than specifically foraging for particular species [15]. In this case, the main drivers of earthworm predation are likely to be the relative abundance of each earthworm species, and their ecological guild, i.e. position in the soil profile. Typically, epigeic earthworm species (living in the leaf litter) and anecic species (living in deep burrows, but foraging in the litter at night) would be more likely to be predated than would endogeic ones (living almost exclusively in the soil) [50]. A quantitative assessment of earthworm populations would allow the comparison between earthworm abundance and predation. However, as mentioned by other authors, such assessment is difficult to produce because of biases in earthworm sampling methods, difficulty in 


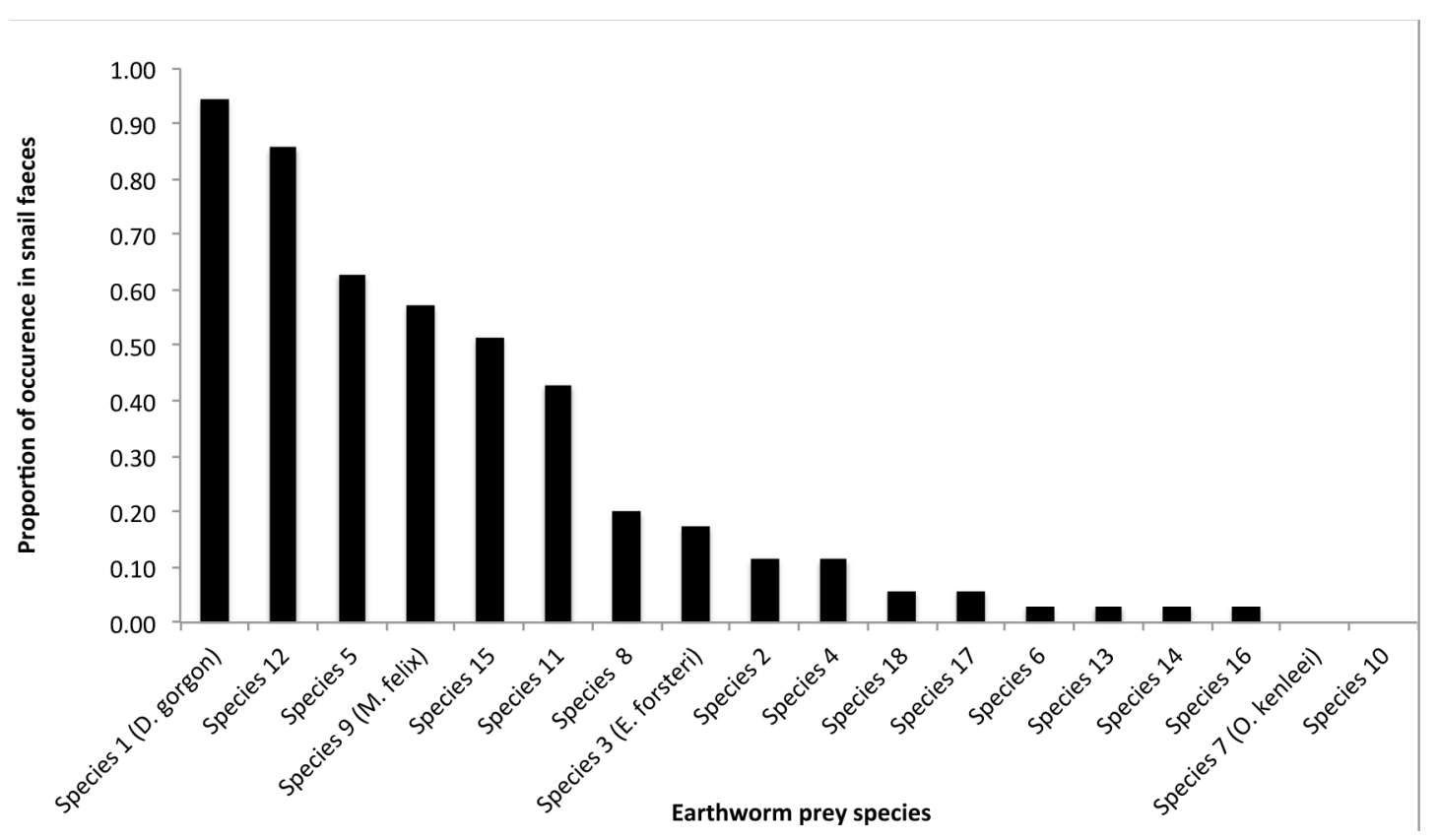

Figure 4. Frequency of occurrence of each species of earthworm in the diet of $\boldsymbol{P}$. augusta. Proportion of faecal strings $(n=35)$ that contained DNA from each earthworm species.

doi: 10.1371/journal.pone.0075962.g004

identifying juveniles and patchy distribution of earthworms in heterogeneous habitats [53]. In our case, it was made even more difficult because most earthworm species were undescribed and more importantly most of the snail original habitat had been lost to coal mining. There is therefore little information available about the abundance of these earthworm species; however, some ecological data exist for four species included in the inventory. O. kenleei (species 7) was described as endogeic [41] and was not detected in any of the analysed snail faecal samples. $D$. gorgon (species 1) and $M$. felix (species 9) were both described as anecic [41] and these were found in $94 \%$ and $51 \%$ of the faecal samples, respectively. $E$. forsteri, described as epigeic [40], was found in $6 \%$ of the faecal samples. This seems to support the hypothesis that snails forage randomly through the litter and predate any earthworm they encounter.

\section{Application of NGS to diet analyses}

Next-generation sequencing provides a good compromise in terms of precision in species identification, information obtained (DNA sequences), and prompt delivery of results. In addition, many samples can be analysed simultaneously for little additional cost. The use of molecular tags allows mixing of samples from different origins in a single reaction [45]. With decreasing costs, NGS is destined to become a standard tool for the study of endangered predatory species that are difficult to observe directly. However, the diet analysis protocol used here demands a precise framework to be applied:

(1) A comprehensive inventory of the potential prey species is required, at least at the level of higher taxonomic ranks, to design appropriate group-specific primers. Unexpected prey can be detected and identified a posteriori if the group-specific primers are general enough to amplify their DNA.

(2) Because many NGS systems are currently limited in the length of the fragments they can process, amplicons must be short (often $<250 \mathrm{bp}$ ). Although, on-going improvement of NGS technologies (e.g. $454 \mathrm{FLX}+$, Ion PGM) as well as the development of new sequencing platforms (e.g. PacBios RS) may rapidly overcome this size limitation [54], short amplicons will remain a constraint for degraded DNA.

(3) The choice of a small target fragment or "mini-barcode" is crucial. It must be short enough for compatibility with NGS and degraded DNA, but informative enough to ensure accurate species identification. We recommend using objective tools such as the sliding window function in the $R$ package SPIDER [42] to optimise identification performance with short amplicons.

\section{Conclusion}

Our study reveals that $P$. augusta can predate a broad range of earthworm species and probably feeds on any species of earthworm that is available to them. The variety of prey reflects the diversity of earthworm species present in the Stockton plateau. Such non-specificity has important implications for the conservation management of $P$. augusta. The choice of new relocation areas, the feeding protocol for captive snails, and the ecological restoration of their original habitat are simplified because a range of earthworm communities seems to be suitable for providing prey to snails in all these conditions. More generally, the development of such methods has major 
implications for the conservation of endangered invertebrate and vertebrate species whose dietary requirements are unknown. This represents a significant improvement compared to traditional methods used in the field of molecular analyses of predation [14].

\section{Acknowledgements}

Snail faecal samples were provided by Solid Energy New Zealand Limited as part of the rehabilitation programme for the Stockton mine. We thank Paul Weber and Mark Pizey for guidance, and Mark Hamilton for logistical help. We thank

\section{References}

1. Sunderland KD (1987) A review of methods of quantifying invertebrate predation occurring in the field. Acta Phytopathol Entomol Hungarica 22: 13-34

2. Sopp P, Sunderland K, Fenlon J, Wratten S (1992) An improved quantitative method for estimating invertebrate predation in the field using an enzyme-linked immunosorbent assay (ELISA). J Appl Ecol 29: 295-302. Available: http://www.jstor.org/stable/2404498. Accessed 5 October 2011. doi:10.2307/2404498.

3. Fryxell JM, Lundberg P (1994) Diet choice and predator-prey dynamics. Evol Ecol 8: 407-421. doi:10.1007/BF01238191.

4. Lavandero B, Wratten S, Hagler J, Jervis M (2004) The need for effective marking and tracking techniques for monitoring the movements of insect predators and parasitoids. Int J Pest Manag 50: 147-151. Available: http://www.tandfonline.com/doi/abs/ 10.1080/09670870410001731853. Accessed 31 August 2012. doi: 10.1080/09670870410001731853.

5. Turner AM (2008) Predator diet and prey behaviour: freshwater snails discriminate among closely related prey in a predator's diet. Anim Behav 76: 1211-1217. doi:10.1016/j.anbehav.2008.06.005.

6. King RA, Vaughan IP, Bell JR, Bohan DA, Symondson WOC (2010) Prey choice by carabid beetles feeding on an earthworm community analysed using species- and lineage-specific PCR primers. Mol Ecol 19: 1721-1732. Available: http://www.ncbi.nlm.nih.gov/pubmed/ 20345680. Accessed 29 September 2011. doi:10.1111/j.1365-294X. 2010.04602.x. PubMed: 20345680.

7. Clare EL, Fraser EE, Braid HE, Fenton MB, Hebert PDN (2009) Species on the menu of a generalist predator, the eastern red bat (Lasiurus borealis): using a molecular approach to detect arthropod prey. Mol Ecol 18: 2532-2542. Available: http://www.ncbi.nlm.nih.gov/ pubmed/19457192. Accessed 23 June 2011. doi:10.1111/j.1365-294X. 2009.04184.x. PubMed: 19457192.

8. Symondson WOC (2002) Molecular identification of prey in predator diets. Mol Ecol 11: 627-641. Available: http://www.ncbi.nlm.nih.gov/ pubmed/11972753. doi:10.1046/j.1365-294X.2002.01471.x. PubMed: 11972753.

9. Merfield C, Wratten S, Navntoft S (2004) Video analysis of predation by polyphagous invertebrate predators in the laboratory and field. Biol Contr 29: 5-13. Available: http://linkinghub.elsevier.com/retrieve/pii/ S1049964403000951. Accessed 18 January 2013. doi:10.1016/ S1049-9644(03)00095-1.

10. Deagle BE, Tollit DJ, Jarman SN, Hindell MA, Trites AW et al. (2005) Molecular scatology as a tool to study diet: analysis of prey DNA in scats from captive Steller sea lions. Mol Ecol 14: 1831-1842. Available: http://www.ncbi.nlm.nih.gov/pubmed/15836654. Accessed 28 July 2011. doi:10.1111/j.1365-294X.2005.02531.x. PubMed: 15836654.

11. Hibert F, Sabatier D, Andrivot J, Scotti-Saintagne C, Gonzalez S et al. (2011) Botany, genetics and ethnobotany: a crossed investigation on the elusive tapir's diet in French Guiana. PLOS ONE 6: e25850. Available: $\quad$ http://www.pubmedcentral.nih.gov/articlerender.fcgi? artid=3185057\&tool=pmcentrez\&rendertype=abstract. Accessed 19 January 2013. doi:10.1371/journal.pone.0025850. PubMed: 21991372.

12. Reid B, Ordish RG, Harrison M (1982) An analysis of the gizzard contents of 50 North Island brown kiwis, Apteryx australis mantelli, and notes on feeding observations. N Z J Ecol 5: 76-85.

13. Bohmann K, Monadjem A, Lehmkuhl Noer C, Rasmussen M, Zeale MRK et al. (2011) Molecular Diet Analysis of Two African Free-Tailed Bats (Molossidae) Using High Throughput Sequencing. PLOS ONE 6: e21441. doi:10.1371/journal.pone.0021441. PubMed: 21731749.
Rudiger Brauning (Agresearch) for his help with the bioinformatics analysis.

Data availability: Raw DNA sequence data fro the pyrosequencing analysis and earthworm DNA library (fasta format) are available on Dryad doi: to be advised

\section{Author Contributions}

Conceived and designed the experiments: SB SDW JA AH RHC. Performed the experiments: SB. Analyzed the data: SB JA. Contributed reagents/materials/analysis tools: SB SDW RHC. Wrote the manuscript: SB SDW AH JA RHC.

14. King RA, Read DS, Traugott M, Symondson WOC (2008) Molecular analysis of predation: a review of best practice for DNA-based approaches. Mol Ecol 17: 947-963. Available: http:// www.ncbi.nlm.nih.gov/pubmed/18208490. Accessed 7 September 2011. doi:10.1111/j.1365-294X.2007.03613.x. PubMed: 18208490.

15. Boyer S, Yeates GW, Wratten SD, Holyoake A, Cruickshank RH (2011) Molecular and morphological analyses of faeces to investigate the diet of earthworm predators: example of a carnivorous landsnail endemic to New Zealand. Pedobiologia 54S: S153-S158. Available: http:// linkinghub.elsevier.com/retrieve/pii/S0031405611000692. Accessed 29 September 2011

16. Jarman SN, Deagle BE, Gales NJ (2004) Group-specific polymerase chain reaction for DNA-based analysis of species diversity and identity in dietary samples. Mol Ecol 13: 1313-1322. Available: http:// www.ncbi.nlm.nih.gov/pubmed/15078466. Accessed 11 June 2011. doi: 10.1111/j.1365-294X.2004.02109.x. PubMed: 15078466.

17. Deagle BE, Gales NJ, Evans K (2007) Studying seabird diet through genetic analysis of faeces: a case study on macaroni penguins (Eudyptes chrysolophus). PLOS ONE 2: e831. Available: http:// dx.plos.org/10.1371/journal.pone.0000831. Accessed 4 January 2013. doi:10.1371/journal.pone.0000831. PubMed: 17786203.

18. Agusti N, De Vicente MC, Gabarra R (1999) Development of sequence amplified characterized region (SCAR) markers of Helicoverpa armigera: a new polymerase chain reaction-based technique for predator gut analysis. Mol Ecol 8: 1467-1474. doi:10.1046/j.1365-294x. 1999.00717.x. PubMed: 10564452.

19. Zaidi RH, Jaal Z, Hawkes NJ, Hemingway J, Symondson WOC (1999) Can multiple-copy sequences of prey DNA be detected amongst the gut contents of invertebrate predators? Mol Ecol 8: 2081-2087. Available: http://www.ncbi.nlm.nih.gov/pubmed/10632859. doi: 10.1046/j.1365-294x.1999.00823.x. PubMed: 10632859

20. Chen Y, Giles KL, Payton ME, Greenstone MH (2000) Identifying key cereal aphid predators by molecular gut analysis. Mol Ecol 9: 18871898. Available: http://www.ncbi.nlm.nih.gov/pubmed/21863559. doi: 10.1046/j.1365-294x.2000.01100.x. PubMed: 11091324.

21. Hoogendoorn M, Heimpel GE (2001) PCR-based gut content analysis of insect predators: using ribosomal ITS-1 fragments from prey to estimate predation frequency. Mol Ecol 10: 2059-2067. Available: http://www.ncbi.nlm.nih.gov/pubmed/11555249. doi:10.1046/j. 1365-294X.2001.01316.x. PubMed: 11555249.

22. Deagle BE, Eveson JP, Jarman SN (2006) Quantification of damage in DNA recovered from highly degraded samples -- a case study on DNA in faeces. Front Zool 3. doi:10.1186/1742-9994-3-11.

23. King RA, Moreno-Ripoll R, Agustí N, Shayler SP, Bell JR et al. (2011) Multiplex reactions for the molecular detection of predation on pest and nonpest invertebrates in agroecosystems. Mol Ecol Resour 11: 370373. Available: http://www.ncbi.nlm.nih.gov/pubmed/21429146. Accessed 22 September 2011. doi:10.1111/j.1755-0998.2010.02913.x. PubMed: 21429146.

24. Šimenc J, Potočnik U (2011) Rapid differentiation of bacterial species by high resolution melting curve analysis. Appl Biochem Microbiol 47: 256-263. Available: http://www.springerlink.com/index/10.1134/ S0003683811030136. Accessed 29 September 2011. doi:10.1134/ S0003683811030136.

25. Chelsky Budarf A, Burfeind DD, Loh WKW, Tibbetts IR (2011) Identification of seagrasses in the gut of a marine herbivorous fish using DNA bar coding and visual inspection techniques. J Fish Biol 79: 112-121. Available: http://www.ncbi.nlm.nih.gov/pubmed/21722114. 
Accessed 25 July 2011. doi:10.1111/j.1095-8649.2011.02999.x. PubMed: 21722114

26. Suzuki N, Murakami K, Takeyama H, Chow S (2006) Molecular attempt to identify prey organisms of lobster phyllosoma larvae. Fish Sci 72: 342-349. Available: http://www.blackwell-synergy.com/doi/abs/ 10.1111/j.1444-2906.2006.01155.x. doi:10.1111/j. 1444-2906.2006.01155.x.

27. Riemann L, Alfredsson H, Hansen MM, Als TD, Nielsen TG et al. (2010) Qualitative assessment of the diet of European eel larvae in the Sargasso Sea resolved by DNA bar coding. Biol Lett 6: 819-822. Available: http://www.pubmedcentral.nih.gov/articlerender.fcgi? artid $=3001378 \&$ tool $=$ pmcentrez\&rendertype $=$ abstract. Accessed 22 June 2011. doi:10.1098/rsbl.2010.0411. PubMed: 20573615

28. Zeale MRK, Butlin RK, Barker GLA, Lees DC, Jones G (2011) Taxonspecific PCR for DNA bar coding arthropod prey in bat faeces. Mol Ecol Resour 11: 236-244. doi:10.1111/j.1755-0998.2010.02920.x. PubMed: 21429129.

29. Margulies M, Egholm M, Altman WE, Attiya S, Bader JS et al. (2005) Genome sequencing in microfabricated high-density picolitre reactors. Nature 437: 376-380. PubMed: 16056220.

30. Ahmadian A, Ehn M, Hober S (2006) Pyrosequencing: History, biochemistry and future. Clin Chim Acta 363: 83-94. doi:10.1016/ j.cccn.2005.04.038. PubMed: 16165119.

31. Valentini A, Pompanon F, Taberlet $P$ (2009) DNA bar coding for ecologists. Trends Ecol Evol 24: 110-117. doi:10.1016/j.tree. 2008.09.011. PubMed: 19100655

32. Goldberg CS, Pilliod DS, Arkle RS, Waits LP (2011) Molecular detection of vertebrates in stream water: a demonstration using rocky mountain tailed frogs and idaho giant salamanders. PLOS ONE 6: e22746. Available: http://www.ncbi.nlm.nih.gov/pubmed/21818382. Accessed 9 August 2011. doi:10.1371/journal.pone.0022746. PubMed: 21818382.

33. Deagle BE, Chiaradia A, Mclnnes J, Jarman SN (2010) Pyrosequencing faecal DNA to determine diet of little penguins: is what goes in what comes out? Conserv Genet 11: 2039-2048. Available: http://www.springerlink.com/index/10.1007/s10592-010-0096-6. Accessed 1 July 2011. doi:10.1007/s10592-010-0096-6.

34. Walker KJ, Trewick SA, Barker GM (2008) Powelliphanta augusta, a new species of land snail, with a description of its former habitat, Stockton coal plateau, New Zealand. J R Soc N Z 38: 163-186. doi: 10.1080/03014220809510553.

35. Trewick S, Walker K, Jordan C (2008) Taxonomic and conservation status of a newly discovered giant landsnail from Mount Augustus, New Zealand. Conserv Genet 9: 1563-1575. doi:10.1007/ s10592-007-9495-8.

36. Boyer S, Wratten SD (2010) Using molecular tools to identify New Zealand endemic earthworms in a mine restoration project (Oligochaeta: Acanthodrilidae, Lumbricidae, Megascolecidae). Zool Middle East: 31-40. Available: http://apps.isiknowledge.com/ full_record.do? product=WOS\&search mode=GeneralSearch\&qid=1\&SID=Z1C4@|6K mgheh6kB8og\&page $=1 \&$ doc $=6$.

37. Boyer S, Wratten S, Pizey M, Weber P (2011) Impact of soil stockpiling and mining rehabilitation on earthworm communities. Pedobiologia 54S: S99-S102. Available: http://linkinghub.elsevier.com/retrieve/pii/ S0031405611000837. Accessed 29 September 2011.

38. Pop AA, Wink M, Pop VV (2003) Use of 18S, 16S rDNA and cytochrome c oxidase sequences in earthworm taxonomy (Oligochaeta, Lumbricidae). Pedobiologia 47: 428-433. doi: 10.1078/0031-4056-00208

39. Pop AA, Cech G, Wink M, Csuzdi C, Pop VV (2007) Application of 16S, 18S rDNA and COI sequences in the molecular systematics of the earthworm family Lumbricidae (Annelida, Oligochaeta). Eur J Soil Biol 43: S43-S52. Available: http://linkinghub.elsevier.com/retrieve/pii/
S1164556307000891. Accessed 13 September 2011. doi:10.1016/ j.ejsobi.2007.08.007.

40. Lee KE (1959) The earthworm fauna of New Zealand Department of Scientific and Industrial Research Bulletin 130. p

41. Boyer S, Blakemore RJ, Wratten SD (2011) An integrative taxonomic approach to the identification of three new New Zealand endemic earthworm species (Acanthodrilidae, Octochaetidae: Oligochaeta). Zootaxa 2994: 21-32. Available: http://mapress.com/zootaxa/2011/f/ zt02994p032.pdf.

42. Brown SDJ, Collins Ra, Boyer S, Lefort M-C, Malumbres-Olarte J et al. (2012) Spider: An R package for the analysis of species identity and evolution, with particular reference to DNA bar coding. Mol Ecol Resour 12: 562-565. Available: http://www.ncbi.nlm.nih.gov/pubmed/ 22243808. Accessed 7 March 2012. doi:10.1111/j. 1755-0998.2011.03108.x. PubMed: 22243808.

43. Boyer S, Brown SDJ, Collins RA, Cruickshank RH, Lefort M-CD et al. (2012) Sliding window analyses for optimal selection of mini-barcodes, and application to 454- pyrosequencing for specimen identification from degraded DNA. PLOS ONE 7: e38215. Available: http://dx.plos.org/ 10.1371/journal.pone.0038215. Accessed 29 May 2012. doi:10.1371/ journal.pone.0038215. PubMed: 22666489.

44. Boore JL, Brown WM (1995) Complete sequence of the mitochondrialDNA of the annelid worm Lumbricus terrestris. Genetics 141: 305-319. PubMed: 8536978.

45. Parameswaran $\mathrm{P}$, Jalili $\mathrm{R}$, Tao $\mathrm{L}$, Shokralla S, Gharizadeh B et al. (2007) A pyrosequencing-tailored nucleotide bar code design unveils opportunities for large-scale sample multiplexing. Nucleic Acids Res 35: 1-9. doi:10.1093/nar/gkl1051. PubMed: 16920744

46. Team RDC (2009) R: A language and environment for statistical computing.

47. Simon C, Frati F, Beckenbach A, Crespi B, Liu H et al. (1994) Evolution, weighting, and phylogenetic utility of mitochondrial genesequences and a compilation of conserved polymerase chain-reaction primers. Ann Entomol Soc Am 87: 651-701.

48. Altschul SF, Madden TL, Schäffer AA, Zhang J, Zhang Z et al. (1997) Gapped BLAST and PSI-BLAST: a new generation of protein database search programs. Nucleic Acids Res 25: 3389-3402. Available: http:// www.pubmedcentral.nih.gov/articlerender.fcgi?

artid=146917\&tool=pmcentrez\&rendertype=abstract. doi:10.1093/nar/ 25.17.3389. PubMed: 9254694.

49. Ewing B, Hillier L, Wendl MC, Green P (1998) Base-Calling of Automated Sequencer Traces Using Phred. I. Accuracy Assessment. Genome Res 8: 175-185. Available: http://genome.cshlp.org/cgi/doi/ 10.1101/gr.8.3.175. Accessed 28 June 2013. doi:10.1101/gr.8.3.175. PubMed: 9521921.

50. Bouché MB (1972) Lombriciens de France, Ecologie et Systématique. Paris: INRA, Annales de Zoologie --Ecologie animale. $p$

51. Bowles E, Schulte PM, Tollit DJ, Deagle BE, Trites AW (2011) Proportion of prey consumed can be determined from faecal DNA using real-time PCR. Mol Ecol Resour 11: 530-540. doi:10.1111/j. 1755-0998.2010.02974.x. PubMed: 21481211.

52. Murray DC, Bunce M, Cannell BL, Oliver R, Houston J et al. (2011) DNA-Based Faecal Dietary Analysis: A Comparison of qPCR and High Throughput Sequencing Approaches. PLOS ONE 6: e25776. Available: http://dx.plos.org/10.1371/journal.pone.0025776. Accessed 7 October 2011. doi:10.1371/journal.pone.0025776. PubMed: 21998697.

53. Brown DS, Jarman SN, Symondson WOC (2012) Pyrosequencing of prey DNA in reptile faeces: analysis of earthworm consumption by slow worms. Mol Ecol Resour 12: 259-266. Available: http:// www.ncbi.nlm.nih.gov/pubmed/22176947. Accessed 11 March 2013. doi:10.1111/j.1755-0998.2011.03098.x. PubMed: 22176947.

54. Glenn TC (2011) Field guide to next-generation DNA sequencers. Mol Ecol Resour, 11: 759-769. Available: http://www.ncbi.nlm.nih.gov/ pubmed/21592312. Accessed 18 July 2011. PubMed: 21592312. 